\title{
Psikolojik Danışmanlara Yönelik Cinsel Sağlık Eğitici Eğitiminin Etkililiğinin İncelenmesi
}

\author{
Barışcan Öztürk ${ }^{\mathrm{a}, \mathrm{b}}$, Erol ESENc
}

\section{Özet}

Riskli cinsel davranışların sıklıkla görüldüğü ergenlik döneminde, ergenlerin doğru bilgiye ulaşmaları ve ihtiyaç duydukları becerileri geliştirmelerinde kapsamlı cinsel sağlık eğitimi önemli rol oynamaktadır. Cinsel sağllk eğitiminin etkililiğinde önemli unsurlardan biri ise eğiticinin nitelikleridir. Bu çalışmanın amacı, cinsel sağlık eğitici eğitiminin psikolojik danışmanların ergen sağlığına ilişkin yeterlilik algılarına etkisini incelemek ve katılımcılara katkılarını, güçlü ve güçlendirilmesi gereken yönlerini değerlendirmektir. Çalışmada nicel ve nitel verilerin birlikte kullanıldığı karma yöntem desenlerinden biri olan iç içe desen kullanılmıştır. Araştırmanın nicel boyutunda deneysel işlemin etkisini incelemek için tek grup öntest sontest deseni, çalışmanın nitel boyutunda, programın etkilerine dayalı durum çalışması kullanılmıştır. Çalışmaya gönüllü katılımcılar arasında seçkisiz olarak belirlenen 25 psikolojik danışman katılmıştır. Nicel bulgular, cinsel sağlık eğitici eğitiminin katılımcıların ergen sağlığına ilişkin yeterlilik algılarını arttırdığını göstermektedir. Araştırmanın nitel bulguları ise, eğitici eğitiminin katılımcıların beklentilerini karşıladığını, bilgilerini arttırdığı, becerilerini ve farkındalıklarını geliştirdiğini ortaya koymaktadır.
Anahtar Kelimeler

Cinsel Sağllk Eğitimi

Ergenlik

Psikolojik Danışmanlar

Karma Yöntem

Makale Hakkında

Geliş Tarihi: 10.02.2020

Kabul Tarihi: 26.08.2020

Doi: 10.18026/cbayarsos.687101

\section{Investigation of the Effectiveness of Sexual Health Educator Training for Counselors}

\begin{abstract}
In adolescence, when risky sexual behaviors are frequently observed, sexual health education plays a key role in adolescents' access to accurate knowledge and developing the skills they need. One of the important factors in the effectiveness of sexual health education is the qualifications of the educator. The aim of this study is to examine the effects of sexual health educator training program on the counsellors' self-efficacy about adolescent health and to evaluate the contributions of training to the participants. In order to examine the effectiveness of the intervention, embedded mixed methods research design was used in the study. In the quantitative dimension of the research, a single group pretest-posttest design, in qualitative dimension program effects case study was used. The quantitative findings showed that educator training affects the participants' self-efficacy perceptions about adolescent health positively. The qualitative finding of the study pointed out that sexual health educator training meets the expectations of the participants, improves their knowledge, helps to develop their skills and awareness.
\end{abstract}

Keywords

Sexual Health Education

Adolescence

Counselors

Mixed Method

About Article

Received: 10.02 .2020

Accepted: 26.08.2020

Doi: 10.18026/cbayarsos.687101

a İletişim Yazarı: bariscano@hotmail.com

b Dr. Psikolojik Danışman, Bornova Altay Mesleki ve Teknik Anadolu Lisesi, İzmir, ORCID 0000-0003-2789-2718.

c Dr. Öğrt. Üyesi, Manisa Celal Bayar Üniversitesi, Rehberlik ve Psikolojik Danışmanlık ABD., Manisa, ORCID 0000-0002-8285-2666. 


\section{Giriş}

Ergenlerin riskli davranışlarının sonuçları, kendileri kadar ailelerini, içinde bulundukları okulları ve parçası oldukları toplumları da etkilemektedir. Ergenlerin; cinselliğe başlama yaşının düşmesi, istenmeyen gebelikler ve cinsel yolla bulaşan hastalıklar bakımından risk altındaki gruplardan olduğu; bilgilendirme ve eğitim gereksinimlerinin karşılanmamasının sonraki yaşamlarında olumsuz sonuçlara neden olabildiği belirtilmektedir (Sağlık Bakanlığı, 2010). Hem Türkiye' de hem yurt dışında ergenlerle yapılan birçok araştırmanın bulguları da bu tespitleri destekler niteliktedir (Finer ve Philbin, 2013; Herbenick vd., 2010; KorkmazÇetin vd., 2008; Sedgh, Finer, Bankole, Eilers ve Singh, 2015; Siyez ve Siyez, 2007). Nüfusun yaklaşık üçte birini 18 yaşın altındaki bireylerin oluşturduğu Türkiye' de çocukların ve ergenlerin cinsel sağlığa ilişkin bilgilerini arttırmak, riskli cinsel davranışları azaltmak, gerek resmi gerek gönüllü birçok kurum ve kuruluşun hedefleri arasında yer almaktadır (Sağlık Bakanlığı, 2010; Zeren ve Gürsoy, 2018).

Ergenlerin cinsellikle ilgili doğru bilgiye ulaşmalarında ve gerekli becerilerin geliştirilmesinde en etkin yaklaşımların, müdahalelerin başında kapsamlı cinsel sağlık eğitimleri gelmektedir (Goldman, 2008; Haberland ve Rogow, 2015). Cinsel sağlik eğitimi; kimlik, ilişkiler ve cinsel yakınlı gibi önemli konularda yaşam boyu süren bir bilgi edinme, tutum, inanç ve değer oluşturma sürecidir (Sexuality Information and Education Council of the United States [SIECUS], 2004, s. 13). Gelişimsel özelliklere uygunluk, kültüre duyarlılık, cinsellikle ve ilişkilerle ilgili bilimsel olarak doğrulanmış gerçekçi ve yargılayıcı olmayan bilgilerin paylaşılması cinsel sağlık eğitiminin öne çıkan ilkeleridir (Bruess ve Schroeder, 2014).

Riskli cinsel davranışları hedef alan eğitsel müdahaleler ve önleme çalışmaları bakımından işbirliği ve eşgüdüm ihtiyacına vurgu yapılan kurumların başında okullar gelmektedir (Barr, Moore, Johnson, Forrest ve Jordan, 2014; Goldman, 2011; Haberland ve Rogow, 2015; Şahin, 2014; Zeren ve Gürsoy, 2018). Okullar, bireylerin gelişimini etkileyebilecek; çeşitli fiziksel, çevresel ve davranışsal faktörleri ele alan önleyici hizmetleri sunmak için ideal ortamlardan biri olarak görülmektedir (Meyers ve Swerdlik, 2003). Ergenlerin kapsamlı bir cinsel sağlık eğitimine ihtiyaç duydukları ve bu ihtiyacın giderilmesinde okulların önemli bir rolünün olabileceği kabul edilmektedir (St Leger, 1999). Liselerde öğrenim gören ergenlerin önemli bir kısmı da okullarında cinsel sağlık eğitimi almayı istemektedir (Byers vd., 2003). Özellikle, cinselliğin ve bağlantılı konuların tabu olarak görüldüğü ve aile içinde konuşulmasının zor olduğu toplumlarda, okullarda sürdürülen cinsel sağlık eğitimi uygulamaları daha da kritik hale gelmektedir (Lloyd, 2010; Şahin, 2014). Araştırmalar Türkiye'de çoğu ebeveynin çocuklarıyla cinsel konulardaki iletişimlerinin sınırlı olduğunu, çocuklarının cinsellikle ilgili sorularını yanıtlamakta zorlandıklarını ve kendilerini yetersiz hissettiklerini ortaya koymaktadır (Bulut ve Gölbaşı, 2009; Erbil, Orak ve Bektaş, 2010; Eroğlu ve Gölbaşı, 2005).

Ergenler ile çalışan okul psikolojik danışmanları; romantik ilişkiler, cinsel gelişim, beden imgesi, cinsel yönelim gibi birçok farklı konuda öğrencilerinden gelen sorularla karşı karşıya kalabilmektedir (Parker, 2012; Millner ve Upton, 2016; Şahin, 2014). Psikolojik danışmanlar gerek aldıkları eğitimin içeriği gerekse psikolojik danışma hizmetlerinin sunulmasında benimsedikleri ilkeler nedeniyle okullarda cinsel sağllk eğitimi sunabilecek uzmanlar olarak değerlendirilmektedir (Millner ve Upton, 2016; Simons, Brian, ve Bahr, 2017). Okullarda görev yapan öğretmenler ve yöneticiler gibi farklı paydaşlar psikolojik danışmanları cinsellik konusunda uzman olarak gördüklerini (Cupit, 2010; James, 1999; Şahin, 2014), çocuk ve ergenlerle ilgili cinsel konularda kendilerine müşavirlik sunmalarını istediklerini 
belirtmektedirler (James, 1999). Psikolojik danışmanlardan, okullardaki paydaşların yanı sıra ailelere ve daha geniş toplumsal kesimlere de; cinsel gelişim, cinsiyet kimliği gibi konularda müşavirlik hizmeti sunmaları ve hak savunuculuğu yapmaları beklenmektedir (Colbert ve Magouirk Colbert, 2003). Okullarda görev yapan psikolojik danışmanların temel rollerinden biri de; bireylerin iyilik hallerine zarar verecek problem davranışlara yönelik önleyici çalışmalar planlamaları ve yürütmeleridir (The Council for Accreditation of Counseling and Related Programs [CACREP], 2016). Riskli cinsel davranışlarda önlenmesi hedeflenen problem davranışlar arasında değerlendirilmektedir (Korkut-Owen, 2015). Cinsel sağlık eğitiminin temel hedefleri de bu önleyici perspektif ile örtüşmektedir. Ergenlerin erken yaşta ve riskli cinsel davranışlardan kaçınmaları, kapsamlı cinsel sağlık eğitimlerinin öncelikli amaçları arasında yer almaktadır (Sağlık Bakanlığı, 2010; SIECUS, 2004).

Türkiye' deki ortaokul ve lise müfredatlarında cinsel sağlıkla ilgili bir ders olmadığı göz önünde bulundurulduğunda; okul psikolojik danışmanlarının, ergenlere ve ailelerine gelişimsel ve önleyici perspektifte cinsel sağlık eğitimi sunmaya yönelik uygulamalar gerçekleştirmeleri kritik hale gelmektedir. $\mathrm{Bu}$ da, okul psikolojik danışmanlarının cinsel sağlık eğitimine ilişkin yeterliliklerinin arttırılması ve desteklenmesini gerekli kılmaktadır. Psikolojik danışmanların bu konuda kendilerini ne derece yeterli gördüklerine dair algıları da cinsel sağlık eğitimi sunmaya ilişkin eğilimlerini etkileyebilmektedir (Sousa, 2018). Yeterlilik algısı; en yalın haliyle, bireyin belirli durumlarda başarılı olmaya veya görevleri tamamlamaya ilişkin becerilerine olan inancı olarak tanımlanmaktadıdır (Bandura, 1982). Bu çalışmada incelenmesi amaçlanan yeterlilik algısı, psikolojik danışmanların ergen sağlığının bütün boyutlarına ve cinsel sağlık eğitimini etkin bir şekilde sunmaya ilişkin bilgi ve becerilerine dair öz değerlendirmelerini açıklayan bir kavramdır. Yeterlilik algısı yüksek, donanımlı okul psikolojik danışmanları; ergenlerin zorlandıkları, endişelendikleri cinsel konularda önemli destek kaynaklarından biri olma potansiyeline sahiptirler (Roche, 1998). Psikolojik danışmanların cinsel sağlık eğitimi ve cinsel gelişim konularındaki yeterliliklerini arttırmak üzere İl Milli Eğitim Müdürlüğü ile işbirliği içinde “Kendimi Tanıyorum” projesi hayata geçirilmiştir. Proje, iki temel aşamadan oluşmaktadır. Bunlar (1) Ortaokullarda ve liselerde görev yapan psikolojik danışmanların cinsel sağlık eğitimi konusundaki yeterliliklerinin, becerilerini arttırmaya yönelik eğitsel müdahalenin gerçekleştirilmesi, (2) Eğitim alan psikolojik danışmanlar aracılığı ile okullarda ergenlere cinsel sağlı eğitimi sunulmasıdır. Bu çalışmayla projenin birinci aşamasını oluşturan cinsel sağlık eğitici eğitimi programının okul psikolojik danışmanlarının ergen sağlığına ilişkin yeterlilik algılarına etkisinin ve katılımcı psikolojik danışmanların cinsel sağlık eğitici eğitimine ilişkin görüşlerinin incelenmesi amaçlanmaktadır.

\section{Yöntem}

\section{Araştırma Deseni}

Cinsel sağlık eğitici eğitiminin etkililiğini belirlemek amacıyla yapılan çalışmada, nicel ve nitel verilerin birlikte kullanıldığı karma yöntem desenlerinden biri olan iç içe desen kullanılmıştır. İç içe desenin en yaygın örneği nitel verilerin deneysel desene dahil edilmesidir. Böylelikle nicel veriyle ilgili ek bilgi sağlanır ve farklı bakış açılarıyla zenginleştirilir (Creswell, 2012; Creswell ve Plano Clark, 2017). Çalışmanın nicel boyutu deneysel desenlerden biri olan tek grup öntest-sontest desen olarak tasarlanmıştır. Çalışmanın nitel boyutunda, nitel araştırma yöntemlerinden programın etkilerine dayalı durum çalışması kullanılmıştır (Mann, 2006). Durum çalışmalarında temel amaç; durumu, 
kişiyi ya da olguyu, özgün ortamı içinde keşfetmek, analiz etmek ve yorumlamaktır (Paker, 2015). Durum çalışması türlerinden biri olan programın etkilerine dayalı durum çalışmalarında ise uygulanan programların etkisinin değerlendirilmesi, programın başarısının veya başarısızlığının nedenlerine ilişkin çıkarımlara ulaşmak amaçlanır (Mann, 2006).

\section{Katılımcilar}

Çalışma grubunun oluşturulması aşamasında ilk olarak projenin yürütüldüğü il merkezinde, ortaokul, lise ve rehberlik araştırma merkezinde (RAM) çalışan psikolojik danışmanlara eposta aracılığıyla eğitim duyurusu yapılmıştır. Duyuru sonrasında gönüllü katılımcıların başvuruları yine e-posta aracılığıyla alınmıştır.

Başvuran 35 katılımcıdan eğitici eğitiminin üst sınırı olarak belirlenen 25 katılımcı (15 kadın, 10 erkek) seçkisiz olarak çalışma grubuna dahil edilmiştir. Eğitimci eğitiminin 25 kişi ile sınırlandırılmasında kullanılan ısınma etkinliği, grup çalışması gibi yöntem ve tekniklerin verimliliği göz önünde bulundurulmuştur. Katılımcıların \%40'1 (n=10) liselerde, \%36'sı (n=9) ortaokullarda ve \%24'ü (n=6) RAM' da görev yapmakta, \%4'ünün (n=1) 1-4 y1l, \%32'sinin $(n=8)$ 5-9 y1l, \%32' $\operatorname{sinin}(n=8)$ 10-14 yıl, \% 20' $\operatorname{sinin}(n=5)$ 15-20 yıl ve \%12'sinin $(n=3) 20-25$ yıl arasında mesleki deneyimi bulunmaktadır. Katılımcı psikolojik danışmanların sadece \% $\% 8^{\prime}$ i $(n=2)$ daha önce ergen cinsel sağlı̆̆ı ile ilgili eğitim aldığını belirtmiştir.

\section{Cinsel Sağlık Ĕ̆itici Ĕ̆itimi}

Cinsel sağlık alanındaki etkili eğitsel yaklaşımlar; aktif katılımı önemseyen ve kolaylaştıran, katılımcıların bilgiyi kişiselleştirmesine olanak sağlayan, iletişim, karar verme ve eleştirel düşünme becerilerini güçlendiren müdahaleler olarak tanımlanmaktadır (Haberland ve Rogow, 2015). Birleşmiş Milletler Nüfus Fonu (UNFPA) da (2014) kapsamlı cinsel sağlık eğitimlerinin geliştirilmesinde ve uygulanmasında dikkat edilmesi gereken ilkeleri tanımlarken; kültüre uygunluk, katılımcı grubun ihtiyaçlarına göre yapılandırılmış olmak, tüm bireylerin haklarına ve değerlerine saygı duyarak toplumsal cinsiyet rolleri ve romantik ilişkiler (rıza inşası, karar verme, iletişim, flört şiddeti, kadına yönelik şiddet vb.), beden, ergenlik, üreme, cinsel sağlık (cinsel bulaşan enfeksiyonlar, istenmeyen gebelikler, gebelikten korunma yöntemleri, destek hizmetleri ulaşmak vb.) konularında bilimsel olarak doğru bilgiyi sunmak gibi ilkeleri öne çıarmıştır. Psikolojik danışmanlara yönelik cinsel sağlık eğitici eğitiminin içeriğini oluşturacak temaların yapılandırılmasında, öğretim etkinliklerinin seçiminde ve kazandırılması amaçlanan becerilerin belirlenmesinde belirtilen ilkeler ışı̆̆ında hareket edilmiştir.

Eğitici eğitimi, Fisher ve Fisher (1992) tarafından oluşturulan Bilgi, Motivasyon, Davranış Becerileri (IMB) Modeline dayalı olarak geliştirilmiştir. Bu teorik temelin seçilmesinde bu modele dayalı olarak geliştirilen cinsel sağlık eğitimlerinin çok farklı gruplarda etki gösterdiğine dair araştırma bulguları etkili olmuştur (Walsh, Senn, Scott-Sheldon, Vanable ve Carey, 2011). Modele göre güvenli davranışların belirleyicileri; bilgi, motivasyon ve davranışsal becerilerdir. Bilgi riskli davranışlardaki değişim için ön koşul iken, motivasyon ise önleyici davranışlara ilişkin tutumların, önleyici davranışların sergilenmesiyle bağlantılı sosyal normların ve kişisel güvenlik algılarının işlevlerini açılamaktadır. Riski azaltmaya yönelik bilgiler ve motivasyon, davranışsal beceriler aracılığı ile sağlıkla ilgili konularda davranış değişikliğini etkilemektedir (Fisher, Fisher, Miscovich, Kimble ve Malloy, 1996). 
Cinsel sağlık eğitici eğitiminde ele alınan temalar ve bu temalara ayrılan süreler Tablo 1' de yer almaktadır.

Tablo 1. Cinsel Sağlık Eğitici Eğitim Programının Temaları ve Ayrılan Süreler

\begin{tabular}{lc}
\hline Tema & Süre \\
\hline Cinsel eğitim: Kavramlar, yaklaşımlar ve uygulama örnekleri & 8 saat \\
Cinsellik: Cinsel değerler, cinselliğe yaklaşım, cinselliğin boyutları ve mitler & 6 saat \\
Toplumsal cinsiyet & 3 saat \\
Ergenlik ve ergenlik dönemi değişimleri & 3 saat \\
Cinsel organlar ve işlevleri & 2 saat \\
Güvenli cinsellik ve cinsel yolla bulaşan enfeksiyonlar & 4 saat \\
Ergen üreme sağlığının, rehberlik ve psikolojik danışmanlık hizmetlerinde ele alınışı & 4 saat \\
Cinsiyet kimliği ve cinsel yönelim & 4 saat \\
Çocuk hakları ve hak odaklı çalışma & 6 saat \\
\hline
\end{tabular}

Cinsel sağlık eğitici eğitiminde katılımcıların bilgiyi içselleştirmelerini kolaylaştıracak, kendilerini süreçte aktif hissetmelerini ve motivasyonlarının artmasını sağlayacak öğrenen merkezli, interaktif yöntemlerin kullanılmasına dikkat edilmiştir (Brown, 2004; DeLuciaWaack, 2006). Bu çerçevede anlatım yönteminin yanı sıra küçük ve büyük grup çalışması, rol oynama, grup tartışması, video kullanımı ve vaka tartışması tekniklerinden yararlanılmıştır. Ayrıca her oturumunun başlangıcında ısınma alıştırmalarına yer verilerek eğlenceli bir eğitim ortamı oluşturulması hedeflenmiştir.

Eğitim gruplarının etkililiğinde; grup liderinin kişisel özellikleri, liderlik becerileri ve deneyimleri öne çıkan faktörler arasındadır (Cohen, Byers ve Sears, 2012; Corey, Corey ve Corey, 2014; DeLucia-Waack, 2006). Bu bilgilerden hareketle, eğitici kadrosunun farklı disiplinlerden gelen ve cinsel sağlık eğitimi konusunda uygulama deneyimine sahip uzmanlardan oluşturulmasına çaba gösterilmiştir. Eğitici kadrosu, farklı yaş gruplarına yönelik cinsel sağlik eğitimi uygulama deneyimi bulunan bir doktor, bir hemşire, bir sosyolog, bir psikolog ve bir psikolojik danışmandan oluşmaktadır. Her bir eğitmen kendi uzmanlık alanındaki temalarda eğitici eğitiminin ilgili oturumlarını yürütmüşlerdir.

\section{Veri Toplama Araçları}

Cinsel Sağlık Eğitici Eğitimine İlişkin Yarı Yapılandırılmış Görüşme Formu. Form; katılımcıların eğitim programından beklentilerini ve karşılanma düzeylerini, eğitim programının güçlü ve güçlendirilmesi gereken yanlarını, eğitim programının katılımcıların mesleki çalışmalarına yönelik sağladığı/sağlayacağı katkıları belirlemek için kullanılan dört adet açık uçlu sorudan oluşmaktadır. Görüşme sorularının hazırlanma aşamasında, Rehberlik ve Psikolojik Danışmanlık Anabilim Dalında görev yapan üçöğretim üyesinin görüşleri alınmıştır.

Psikolojik Danışmanların Ergen Sağı̆ı̆ına İlişkin Yeterlilik Algısı Değerlendirme Anketi. Psikolojik danışmanların ergen sağlığına ilişkin yeterlilik algısı değerlendirme anketinde, cinsel sağlık eğitici eğitiminde yer alan temalarla bağlantılı olarak hazırlanan 23 madde yer almaktadır. Maddelerin hazırlanmasında eğitim programının temaları (güvenli cinsellik- 3 madde; cinsel eğitim- 3 madde; cinsellik- 3 madde; toplumsal cinsiyet- 1 madde; ergenlik- 3 madde; cinsiyet kimliği ve cinsel yönelim- 4 madde; çocuk hakları ve hak odaklı çalışma- 2 madde; ergen sağlı̆̆ına yönelik müdahalelerin psikolojik danışmanlık hizmetlerine 
bütünleştirilmesi- 4 madde) ve kazanımları dikkate alınmıştır. Formda yer alan her bir madde 1 "Hiç yeterli değil", 9 "Tamamen yeterli" olarak dokuzlu likert tipinde derecelendirilmektedir. Anketin geliştirilme aşamasında ilk aşamada hazırlanan 28 maddelik taslak formun kapsam geçerliliğini test etmek amacıyla uzman görüşüne başvurulmuş ve sekiz konu uzmanından geri bildirim alınmıştır. Bu işlemin sonucunda da her bir maddeye ilişkin kapsam geçerlik indeksleri elde edilmiştir. Veneziano ve Hooper'a (1997) göre 8 uzmana gönderilen bir ankette her bir maddenin kapsam geçerlik indekslerinin $\mathrm{p}<.05$ anlamlı olabilmesi için minimum değerin .78 olması gerekmektedir. Ankette yer alan 5 maddenin kapsam geçerlik oranları .78'in altında olduğu belirlenmiş ve anketten çıkartılmıştır.

\section{Verilerin Toplanması}

Araştırmanın nicel verileri, ön-test ve son-test uygulamaları ile elde edilmiştir. Çalışma grubuna ön-test uygulaması eğitim başlamadan önce, son-test uygulaması ise eğitim sonunda gerçekleştirilmiştir. Yarı yapılandırılmış görüşmeler ise eğitimin tamamlanmasında bir hafta sonra bireysel olarak gerçekleştirilmiştir. Yarı yapılandırılmış görüşmeler aracılığıyla 20 katılımcının görüşleri alınmıştır. Yarı yapılandırılmış görüşmeler 5-8 dakika arasında sürmüştür. İki katılımcının şehir dışında olması, iki katılımcıya ulaşılamaması, bir katılımcının ise hasta olmasından dolayı bu beş kişiyle görüşme gerçekleştirilememiştir. Bu görüşmeler, eğitim grubuna yönelik yanlılı̆̆ ve Psikolojik Danışmanlık alanından bir öğretim üyesi tarafından gerçekleştirilmiştir. Görüşmelerde katılımcıların izniyle ses kaydı alınmıştır.

\section{Verilerin Analizi}

Psikolojik danışmanların ergen sağlı̆̆ına ilişkin yeterlilik algısını değerlendirme anketinden elde edilen nicel veriler SPSS 24.0 istatistik paket programında analiz edilmiştir. Öncelikle elde edilen verilerin normallik varsayımını karşılayıp karşılamadığı test edilmiştir. Bu değerlendirme basıklık, çarpıklık katsayıları ve Shapiro Wilk testi üzerinden yapılmıştır. Maddelerin bir bölümünün normallik varsayımını karşılamaması üzerine deney grubunun ön-test ve son-test puanlarında bir fark olup olmadığı non-parametrik testlerden biri olan Wilcoxon işaretli sıralar testi ile incelenmiştir. Ayrıca, maddelere ait ön-test son-test puanları arasındaki farkın anlamlı çıkması durumunda $r=z / \sqrt{ }$ formülüyle etki büyüklüğü incelenmiştir (Pallant, 2007). Cohen'e (1988) göre .1 değeri düşük, .3 değeri orta ve .5 değeri ise büyük etki boyutunu ortaya koymaktadır.

Yarı yapılandırılmış görüşmeler aracılığıyla elde edilen nitel verilerin analizinde ise içerik analizi tekniği kullanılmıştır. İçerik analizine başlamadan önce görüşmelerin ses kayıtları yazıya dökülmüştür. Görüşme dökümlerinde eksik veya hatalı bölümlerin olup olmadığı bir uzman tarafından kontrol edilmiş ve kontrolü sağlanan görüşme dökümleri üzerinden içerik analizine başlanmıştır. İçerik analizinde Yıldırım ve Şimşek'in (2006) belirttiği gibi üç aşamalı bir yol izlenmiştir. İlk olarak veriler kodlanmış, daha sonra kodlardan yola çıkarak temalar belirlenmiştir. Tema sayısının fazla olduğu sorularda ortak ilişkileri bulunan temalar daha kapsayıcı temalar içerisinde sınıflandırılmıştır. Daha sonra araştırmacılar tarafından kodlar ve kategoriler birçok kez kontrol edilmiştir. Bu işlemlerden sonra araştırmanın birinci yazarı tarafından veriler iki hafta arayla kodlanarak, kodlayıcı güvenirliği hesaplanmıştır. Güvenirlik yüzdesi Miles ve Huberman'nın (1994) Güvenirlik= Görüş Birliği/(Görüş Birliği+Görüş Ayrılığı)X100 formülü kullanılarak hesaplanmıştır. Her bir görüşme sorusu 
için hesaplanan uyuşum yüzdesinin \%91 ile \%100 arasında değiştiği, tüm analizler için ise \%94 olduğu belirlenmiştir. Bu aşamada iç geçerliği arttırmak için uzman incelemesine başvurulmuş, ortaya çıkan temaların yeterli düzeyde veri setini yansıtıp yansıtmadı̆̆ını ve bu temalara göre verilerin etkili bir biçimde düzenlenip düzenlenmediği ile ilgili geri bildirim alınmıştır. Son olarak veriler ortaya çıkan kodlara ve temalara göre düzenlenmiş, araştırmada güvenirliği arttırmak ve yanlılığı azaltmak için (Yıldırım ve Şimşek, 2011) veriler sayısallaştırılarak katılımcı sayısı üzerinden rapor edilmiştir.

\section{Bulgular}

\section{Nicel Bulgular}

Katılımcıların, psikolojik danışmanların ergen sağlığına ilişkin yeterlilik algısı değerlendirme formu öntest ve sontest ölçümlerinin aritmetik ortalamaları, standart sapmaları ve minimum-maksimum değerleri Tablo 2' de yer almaktadır.

Tablo 2. Ön-test Son-test Puan Ortalamaları, Standart Sapma ve Min-Max Değerleri

\begin{tabular}{|c|c|c|c|c|c|c|}
\hline & & Önte & & & Sonte & \\
\hline & $\overline{\boldsymbol{X}}$ & SS & $\begin{array}{l}\text { Min- } \\
\text { Max }\end{array}$ & $\overline{\boldsymbol{X}}$ & SS & $\begin{array}{l}\text { Min- } \\
\text { Max }\end{array}$ \\
\hline 1. Ergen sağllğında ve fiziksel gelişiminde temel bilgilerim & 5.56 & 1.71 & $2-8$ & 7.96 & .98 & $5-9$ \\
\hline 2. Ergen sağlığına genel yaklaşım konusunda bilgilerim & 5.64 & 1.85 & $2-8$ & 8.12 & .88 & $5-9$ \\
\hline $\begin{array}{l}\text { 3. Ergenlerin fiziksel gelişiminde sık karşılaştıkları yakınma ve } \\
\text { sorunlar konusunda bilgilerim }\end{array}$ & 5.84 & 1.72 & $1-9$ & 8.00 & 1.04 & $5-9$ \\
\hline $\begin{array}{l}\text { 4. Mesleki alanım içerisinde ergen sağlığında destek verme ve } \\
\text { yönlendirmeye ilişkin bilgilerim }\end{array}$ & 5.88 & 1.56 & $2-8$ & 8.12 & .83 & 6-9 \\
\hline $\begin{array}{l}\text { 5. Gençlerin cinsel sağlı̆̆ı ve sık karşılaştıkları cinsel sağlık } \\
\text { problemleri konusunda temel bilgilerim }\end{array}$ & 4.92 & 1.58 & $2-8$ & 7.80 & .82 & 6-9 \\
\hline $\begin{array}{l}\text { 6. Cinsel yolla bulaşan enfeksiyonlar, bulaş ve korunma yolları } \\
\text { konusunda temel bilgilerim }\end{array}$ & 5.08 & 1.91 & $2-9$ & 8.08 & .76 & 6-9 \\
\hline $\begin{array}{l}\text { 7. HIV ya da AIDS ile yaşayan bireylere yönelik damgalama ve } \\
\text { ayrımcılık konusunda farkındalığım }\end{array}$ & 6.12 & 1.59 & $4-9$ & 8.44 & .58 & $7-9$ \\
\hline 8. Güvenli cinsel davranışlara yönelik bilgilerim & 5.52 & 1.56 & $3-8$ & 8.36 & .64 & $7-9$ \\
\hline $\begin{array}{l}\text { 9. Günümüzde mevcut cinsellik eğitimi yaklaşımları konusunda } \\
\text { bilgilerim }\end{array}$ & 4.96 & 1.51 & $2-7$ & 7.72 & .79 & 6-9 \\
\hline $\begin{array}{l}\text { 10. Ülkemizde gençlerin üreme sağlığı alanında genel durumu bu } \\
\text { alandaki genel veriler konusunda bilgilerim }\end{array}$ & 4.68 & 1.72 & $1-8$ & 7.68 & .90 & 6-9 \\
\hline $\begin{array}{l}\text { 11. Ülkemizde gençlerin ergen sağlı̆̆ı alanındaki karşılanmamış } \\
\text { ihtiyaçları ve öncelikleri konusunda bilgi ve farkındalığım }\end{array}$ & 5.40 & 1.60 & $2-9$ & 8.04 & .68 & 7-9 \\
\hline $\begin{array}{l}\text { 12. Gençlerin üreme sağlı̆̆ı alanındaki hakları ve bu konudaki hak } \\
\text { ihlalleri ve yansımaları konusunda bilgi ve farkındalığım }\end{array}$ & 5.12 & 1.74 & $1-8$ & 7.80 & .82 & 6-9 \\
\hline $\begin{array}{l}\text { 13. Gelişim dönemine uygun cinsel davranışlara ve uygun } \\
\text { olmayan cinsel davranışlara ilişkin bilgilerim }\end{array}$ & 5.28 & 1.49 & $2-7$ & 8.00 & .82 & 6-9 \\
\hline $\begin{array}{l}\text { 14. Okulda gerçekleşen cinsel davranışla ilgili sorunlarda okul } \\
\text { idaresiyle hangi konuların paylaşılacağına, nasıl paylaşılması } \\
\text { gerektiğine ve nelere dikkat edileceğine yönelik bilgilerim }\end{array}$ & 5.68 & 1.52 & $3-8$ & 7.64 & .95 & $5-9$ \\
\hline $\begin{array}{l}\text { 15. Okulda gerçekleşen cinsel davranışla ilgili sorunlarda aileyle } \\
\text { hangi konuların paylaşılacağına, nasıl paylaşılması gerektiğine } \\
\text { ve nelere dikkat edileceğine yönelik bilgilerim }\end{array}$ & 5.68 & 1.55 & $2-8$ & 7.72 & .74 & 6-9 \\
\hline
\end{tabular}


16. Cinsel gelişimle ilgili sorun yaşamış bir ergenle yapılabilecek psikolojik danışma oturumlarında dikkat edilmesi gereken noktalar hakkında genel bilgilerim

17. Cinsel yönelim ve cinsiyet kimliği hakkında bilgilerim

18. Okullarda yaşanan cinsel yönelim ve cinsiyet kimliği temelli ayrımcılık hakkında bilgilerim

$\begin{array}{llllll}5.48 & 1.56 & 2-8 & 7.36 & .99 & 5-9 \\ 5.36 & 1.55 & 3-8 & 8.04 & .73 & 7-9 \\ 5.16 & 1.93 & 2-9 & 7.80 & .76 & 7-9 \\ 4.92 & 1.85 & 1-8 & 7.80 & .96 & 5-9 \\ 5.16 & 1.55 & 3-8 & 7.76 & .93 & 6-9 \\ 6.60 & 1.71 & 3-9 & 8.12 & .73 & 7-9 \\ 6.48 & 1.69 & 2-9 & 8.04 & .84 & 6-9 \\ 6.12 & 1.56 & 1-9 & 8.04 & .93 & 6-9\end{array}$

Tablo 2'de görüldügü gibi maddelerin son-test ortalamaları ön-test ortalamalarına göre artmıştır. Psikolojik danışmanların ergen sağlığına ilişkin yeterlilik algısı değerlendirme formundan elde edilen ön-test ve son-test puan ortalamaları arasında anlamlı bir farkın olup olmadığına ilişkin Wilcoxon işaretli sıralar testi sonuçları Tablo 3 'te verilmiştir.

Tablo 3. Katılımcı Puanlarının Wilcoxon İşaretli Sıralar Testi Sonuçları

\begin{tabular}{|c|c|c|c|c|c|c|}
\hline & Sontest- Öntest & $\mathbf{N}$ & Sira ortalaması & S1ra toplamı & $\mathbf{z}$ & $\mathrm{p}$ \\
\hline \multirow[t]{3}{*}{ Madde 1} & Negatif sira & 0 & 0 & 0 & $-4.411^{*}$ & .000 \\
\hline & Pozitif sıra & 25 & 13.00 & 525.00 & & \\
\hline & Eşit & 0 & & & & \\
\hline \multirow[t]{3}{*}{ Madde 2} & Negatif sira & 0 & 0 & 0 & & \\
\hline & Pozitif sıra & 24 & 12.50 & 300.00 & $-4.340^{*}$ & .000 \\
\hline & Eşit & 1 & & & & \\
\hline \multirow[t]{3}{*}{ Madde 3} & Negatif sira & 0 & 0 & 0 & & \\
\hline & Pozitif sıra & 22 & 11.50 & 253.00 & $-4.149^{*}$ & .000 \\
\hline & Eşit & 3 & & & & \\
\hline \multirow[t]{3}{*}{ Madde 4} & Negatif sira & 0 & 0 & 0 & & \\
\hline & Pozitif sira & 24 & 12.50 & 300.00 & $-4.321^{*}$ & .000 \\
\hline & Eşit & 1 & & & & \\
\hline \multirow[t]{3}{*}{ Madde 5} & Negatif sira & 0 & 0 & 0 & & \\
\hline & Pozitif sıra & 25 & 13.00 & 325.00 & $-4.411^{*}$ & .000 \\
\hline & Eşit & 0 & & & & \\
\hline \multirow[t]{3}{*}{ Madde 6} & Negatif sira & 0 & 0 & 0 & & \\
\hline & Pozitif sura & 22 & 11.50 & 253.00 & $-4.125^{*}$ & .000 \\
\hline & Eşit & 3 & 0 & 0 & & \\
\hline \multirow{3}{*}{ Madde 7} & Negatif sira & 0 & 0 & 0 & & \\
\hline & Pozitif sıra & 21 & 11.00 & 231.00 & $-4.049^{*}$ & .000 \\
\hline & Eşit & 4 & & & & \\
\hline \multirow[t]{3}{*}{ Madde 8} & Negatif sıra & 0 & 0 & 0 & & \\
\hline & Pozitif sıra & 25 & 13.00 & 325.00 & $-4.401^{*}$ & .000 \\
\hline & Eşit & 0 & & & & \\
\hline
\end{tabular}




\begin{tabular}{|c|c|c|c|c|c|c|}
\hline \multirow[t]{3}{*}{ Madde 9} & Negatif sira & 0 & 0 & 0 & & \\
\hline & Pozitif sira & 23 & 12.00 & 276.00 & $-4.233^{*}$ & .000 \\
\hline & Eşit & 2 & & & & \\
\hline \multirow[t]{3}{*}{ Madde 10} & Negatif sira & 0 & 0 & 0 & & \\
\hline & Pozitif sıra & 24 & 12.50 & 300.00 & $-4.321^{*}$ & .000 \\
\hline & Eşit & 1 & & & & \\
\hline \multirow[t]{3}{*}{ Madde 11} & Negatif sira & 0 & 0 & 0 & & \\
\hline & Pozitif sıra & 23 & 12.00 & 276.00 & $-4.248^{*}$ & .000 \\
\hline & Eşit & 2 & & & & \\
\hline \multirow[t]{3}{*}{ Madde 12} & Negatif sira & 0 & 0 & 0 & & \\
\hline & Pozitif sira & 23 & 12.00 & 276.00 & $-4.248^{*}$ & .000 \\
\hline & Eşit & 2 & & & & \\
\hline \multirow[t]{3}{*}{ Madde 13} & Negatif sira & 1 & 2.00 & 2.00 & & \\
\hline & Pozitif sira & 23 & 12.96 & 298.00 & $-4.280^{*}$ & .000 \\
\hline & Eşit & 1 & & & & \\
\hline \multirow[t]{3}{*}{ Madde 14} & Negatif sira & 0 & 0 & 0 & & \\
\hline & Pozitif sira & 21 & 11.00 & 231.00 & $-4.132^{*}$ & .000 \\
\hline & Eşit & 4 & & & & \\
\hline \multirow[t]{3}{*}{ Madde 15} & Negatif sira & 0 & 0 & 0 & & \\
\hline & Pozitif sıra & 21 & 11.00 & 231.00 & $-4.053^{*}$ & .000 \\
\hline & Eşit & 4 & & & & \\
\hline \multirow[t]{3}{*}{ Madde 16} & Negatif sıra & 0 & 0 & 0 & & \\
\hline & Pozitif sira & 20 & 10.50 & 210.00 & $-3.983^{*}$ & .000 \\
\hline & Eşit & 5 & & & & \\
\hline \multirow[t]{3}{*}{ Madde 17} & Negatif sira & 0 & 0 & 0 & & \\
\hline & Pozitif sira & 23 & 12.00 & 276.00 & $-4.227^{*}$ & .000 \\
\hline & Eşit & 2 & & & & \\
\hline \multirow[t]{3}{*}{ Madde 18} & Negatif sira & 0 & 0 & 0 & & \\
\hline & Pozitif sıra & 23 & 12.00 & 276.00 & $-4.219^{*}$ & .000 \\
\hline & Eşit & 2 & & & & \\
\hline \multirow[t]{3}{*}{ Madde 19} & Negatif sira & 0 & 0 & 0 & & \\
\hline & Pozitif sira & 24 & 12.50 & 300.00 & $-4.307^{*}$ & .000 \\
\hline & Eşit & 1 & & & & \\
\hline \multirow[t]{3}{*}{ Madde 20} & Negatif sira & 0 & 0 & 0 & & \\
\hline & Pozitif sıra & 23 & 12.00 & 276.00 & $-4.234^{*}$ & .000 \\
\hline & Eşit & 2 & & & & \\
\hline \multirow[t]{3}{*}{ Madde 21} & Negatif sira & 0 & 0 & 0 & & \\
\hline & Pozitif sira & 16 & 8.00 & 120.00 & $-3.555^{*}$ & .000 \\
\hline & Eşit & 9 & & & & \\
\hline \multirow[t]{3}{*}{ Madde 22} & Negatif sira & 0 & 0 & 0 & & \\
\hline & Pozitif sıra & 15 & 8.00 & 120.00 & $-3.427^{*}$ & .001 \\
\hline & Eşit & 10 & & & & \\
\hline \multirow[t]{3}{*}{ Madde 23} & Negatif sira & 0 & 0 & 0 & & \\
\hline & Pozitif sira & 21 & 11.00 & 231.00 & $-4.051^{*}$ & .000 \\
\hline & Eşit & 4 & & & & \\
\hline
\end{tabular}

${ }^{*}$ Negatif siralar temeline dayalı

Tablo 3’te görüldüğü gibi, cinsel sağlık eğitici eğitimi öncesi ve sonrası katılımcıların ergen sağlığına ilişkin yeterlilik algısı değerlendirme formunda yer alan maddelere verdikleri puanlar arasında istatiksel olarak anlamlı bir fark bulunmaktadır. Fark puanlarının sıra 
toplamları dikkate alındığında, gözlenen bu farkın pozitif sıralar, yani sontest puanı lehine olduğu görülmektedir. Bu sonuçlara göre, cinsel sağlık eğitici eğitimi okul psikolojik danışmanlarının ergen sağlığına ilişkin yeterlilik algılarında anlamlı bir etkisinin olduğu söylenebilir.

Tüm maddelerde son-test lehine istatistik olarak anlamlı bulunan bu farkların etki büyüklükleri hesaplanmıştır. Maddelerin etki büyüklüklerinin (Cohen d) .69 ila .88 arasında değiştiği ve eğitici eğitiminin tüm maddelerde büyük ölçüde etkili olduğu görülmektedir. Bu sonuçlara göre cinsel sağlık eğitici eğitiminin katılımcıların ergen sağlığına ilişkin yeterlilik algılarında önemli bir etkisi olduğu söylenebilir.

\section{Nitel Bulgular}

Yarı yapılandırılmış görüşmelerin nitel veri analizi sonucunda cinsel sağlık eğitici eğitimine ilişkin katılımcı görüşleri "Beklentiler", "Değerlendirme" ve "Etkiler" olarak üç kategori altında toplanmıştır. Katılımcıların, cinsel sağlık eğitici eğitiminine ilişkin görüşlerinin analiz sonuçları Tablo 4'te yer almaktadır.

Tablo 4. Katılımcların Cinsel Sağlık Eğitici Eğitimine İlişkin Görüşleri

\begin{tabular}{|c|c|c|c|}
\hline Kategori & Tema & Kod & $\mathbf{N}$ \\
\hline \multirow{8}{*}{ Beklentiler } & \multirow{2}{*}{ Cinsel sağlık eğitimi } & Bilgi & 9 \\
\hline & & Uygulama becerisi & 8 \\
\hline & \multirow{2}{*}{ Ergen üreme sağlığ1 } & Bilgi & 7 \\
\hline & & Yardım becerisi & 4 \\
\hline & \multirow{4}{*}{ Eğitici eğitimi } & Yapılandırılmış & 4 \\
\hline & & Kapsaml & 2 \\
\hline & & Güncel/Bilimsel & 2 \\
\hline & & Yararli & 2 \\
\hline \multirow{8}{*}{ Değerlendirme } & \multirow{4}{*}{ Eğitim programı } & İçerik & 19 \\
\hline & & Yöntem ve teknikler & 10 \\
\hline & & Süre & 3 \\
\hline & & Zaman yönetimi & 4 \\
\hline & \multirow{2}{*}{ Eğitim ortamı } & Samimi iletişim & 4 \\
\hline & & Fiziki donanım & 2 \\
\hline & \multirow{2}{*}{ Eğitimciler } & Yetkinlik & 15 \\
\hline & & Kişisel nitelikler & 6 \\
\hline \multirow{4}{*}{ Etkiler } & \multirow{3}{*}{ Katılımcilara } & Bilgi veren & 15 \\
\hline & & Beceri geliştiren & 9 \\
\hline & & Farkındalık sağlayan & 6 \\
\hline & Öğrencilere & Sunulan hizmetlere katkı sağlayan & 12 \\
\hline
\end{tabular}

Beklentiler. Bu kategori altında cinsel sağllk eğitimi, ergen üreme sağhı̆ğ ve eğitimci eğitimi olamak üzere üç tema yer almaktadır. Cinsel sağlık eğitimi teması altında bilgi ve uygulama becerisi olmak üzere iki kod bulunmaktadır. Katılımcılar cinsel sağlık eğitimi ile ilgili bilgilerini arttırmayı $(n=9)$ ve uygulama becerisi kazanmayı $(n=8)$ beklediklerini ifade etmiştir. Katılımcılar bu beklentilerini, "Cinsel sağlık eğitiminin gençlere ulaştırabilmek için kendi bilgi, becerileri ve farkındalıklarımı arttırmak." [K 4], "Çocuklarda cinsel sağlık eğitimini verebilmek için gereken becerileri kazanmaktı." [K 6], "Ortaokul ve lise düzeyinde cinsel sağlık eğitiminin içeriği, 
cinsel kimlik ve toplumsal cinsiyet hakkında bilgi edinmek istiyordum." [K 10], "Cinsel sağlik eğitiminde çalıştı̆̆ım kademe öğrencilerine yönelik verebileceğim bilgiler beklentimdi." [K 17] şeklinde ifade etmiştir.

Ergen üreme sağlığı teması altında bilgi ve yardım becerisi olmak üzere iki kod yer almaktadır. Katılımcılar ergen üreme sağlığına ilişkin bilgilerini arttırmayı $(n=7)$ ve ergenlere yönelik yardım becerilerini geliştirmeyi $(n=4)$ beklediklerini ifade etmiştir. Katılımcılar bu beklentilerini, "Fiziksel gelişim, cinsel kimlik gelişimi, flört şiddeti, toplumsal cinsiyet eşitliği, riskli davranışlar ve güvenli cinsellik gibi konular içeren ve yüzeysel olmayan bir eğitim beklentim vardı." [K 7], "Öğrencilere faydalı bilgiler vermekti." [K 19], "Ergenlerle birlikte çalıştığım için onlara yaşadıkları zorluklarda yardımoı olmaktı." [K 1] şeklinde ifade etmiştir.

Eğitici eğitimi teması altında ise yapılandırılmış, kapsamlı, güncel/bilimsel ve yararlı olmak üzere dört kod bulunmaktadır. Katılımclar cinsel sağlık eğitici eğitiminin; öğrencilere yönelik yapılandırılmış cinsel sağlık eğitimi sunması $(n=4)$, kapsamlı $(n=2)$, güncel/bilimsel $(n=2)$ ve yararlı olması $(n=2)$ ile ilgili beklentilerini şu şekilde ifade etmiştir; "Cinsellik konusunda çocuk ve ergenlere yönelik iyi yapılandırılmış bir program beklentisiyle katılmıştım." [K 20], "Fiziksel gelişim, cinsel kimlik gelişimi, flört şiddeti, toplumsal cinsiyet eşitliği, riskli davranışlar ve güvenli cinsellik gibi konular içeren ve yüzeysel olmayan bir eğitim beklentim vardı." [K 7], "Cinsel sağlık ile ilgili daha akademik bilgiler eşliğinde kendimi bu konuda daha bilgili hale getirebilmek." [K 12], "Yapılandırılmış ve yararlı bir cinsel sağlık bilgisi elde etmek istiyordum." [K 15].

Değerlendirme. Bu kategori altında eğitim programı, eğitim ortamı, eğitimciler olarak üç tema yer almaktadır. Eğitim programı teması altında içerik, yöntem ve teknikler, süre ve zaman yönetimi olmak üzere dört kod bulunmaktadır. Katılımcıların bazıları eğitim programının içeriğinin ( $n$ = 9) yeterli olduğunu belirtirken, bazı katılımcılar eğitim içeriğine bazı konuların eklenebileceğini $(n=7)$, bazı katılımcılar ise konuların bir kısmının eğitim içeriğinden çıkartılabileceği $(n=3)$ belirtmiştir. Katılımcılar eğitim içeriğinin yeterli olduğu ile ilgili görüşlerini "Konular çok kapsamlı olarak ele alındı." [K 8] ve "Eğitimde konuları çok tatmin edici buldum. Konular yetkin uzmanlar tarafindan hiç bir tabu olmaksızın ve bilimsel referanslara dayalı olarak anlatıldı." [K 17] şeklinde, eğitimin içeriğine bazı konuların eklenebileceği ile ilgili görüşlerini "En son işlenen çocuk hakları ve değerlerin yerine sağlıkl cinsel eğitimler her sınıf kademesinde nasıl verileceği konusunda yapılandırılmış oturum örnekleri verilebilir." [K 1] ve "Ergenlik döneminde yaşanan psikolojik ve sosyal değişimler eklenebilir." [K 10] şeklinde, konuların bir kısmının içerikten çıkartılabileceği ile ilgili görüşlerini ise "Çocuk hakları konusu daha etkili anlatılabilir, iletişim konusu ise katılımo meslek özelliklerine göre anlatılmayabilirdi." [K 16] şeklinde dile getirmiştir. İçeriğe bazı konuların eklenmesini isteyen katılımcıların cinsel kimlik gelişimi, ergenlik dönemi değişiklikleri, rıza inşası ve okullardaki cinsel eğitim uygulamalarında karşılaşılabilecek sorunlar ve çözüm yollarının eklenmesini istedikleri görülürken, içerikten bazı konuların çıkarılabileceği yönünde görüş bildiren katılımcıların ise çocuklarla hak temelli çalışma ve bu tema içinde ele alınan iletişim konularından bahsettikleri görülmektedir. Katılımcıların bir kısmı eğitiminde kullanılan yöntem ve tekniklerin $(n=7)$ etkili olduğu ile ilgili görüşlerini, "Konuların işlenişi, yapılan etkinlikler ve eğitimcilerin sunum becerileri programın güçlü yanlarıydı." [K 6] ve "Eğitim yöntem ve teknikleri çok uygundu. Etkinlikler sayesinde zamanın nasıl geçtiğini anlamadık yani eğlenerek öğrendik" şeklinde ifade etmiştir. Bir katılımcı $(n=1)$ programda etkinlik sayısının arttırılmasını, iki katılımcı $(n=2)$ ise vaka analizine/paylaşımına yer verilmesi gerektiğini belirtmiştir. Katılımcılar bu konudaki görüşlerini şu şekilde ifade etmiştir; "Cinsel gelişimi genel olarak 
kimlik gelişimi sürecinin içine oturtularak anlatımı ve vaka örnekleri olsa program daha güzel olabilirdi." [K 7], "Yaş düzeylerine göre uygulanacak etkinliklerin sayıları artırılabilir." [K 8] ve "İletişim modülü çıkartılıp vaka paylaşımı daha çok olabilir." [K 13]. Üç katılımcı eğitim süresinin yetersiz olduğu ve bu nedenle sürenin arttırılması gerektiği $(n=3)$ ile ilgili görüşlerini "Eğitim saatinin arttırılması katılımcıların yeterince söz almaları açısından faydalı olabilir." [K 9], "Süre bizim grup için yeterli değildi." [K 15] şeklinde ifade etmiştir. Bazı katılımcılar ise zaman yönetimi $(n=4)$ konusunda eksiklikler bulunduğunu belirtmiştir. Katılımcılar görüşlerini "Zaman yönetimi yani grubun ihtiyacına göre programda değissiklik yapabilme esnekliği olmalıydı."

[K 3] ve "Zamanla ilgili sıkışıklı̆̆ın ortadan kalkması için cuma günü yapılan iletişim eğitimi kaldırılabilirdi." [K 18] şeklinde ifade etmiştir.

Eğitim ortamı teması altında samimi iletişim ve fiziki donanım olmak üzere iki kod bulunmaktadır. Katılımcılar eğitim ortamının samimi ve açık iletişim için uygun olduğunu $(n=4)$ ve fiziki donanımın $(n=2)$ yeterli olduğunu belirtmiştir. Bir katılımcı bu konudaki görüşlerini "Eğitim boyunca kabul edici bir yaklaşım vardı." [K 1] şeklinde ifade ederken bir başka katılımcı "Eğitimi veren uzmanlar alanlarında çok hakimdi ve bilgilerini bizimle çok samimi bir ortamda paylaştılar." [K 12] şeklinde ifade etmiştir. Fiziki donanımla ilgili olarak ise katılımcılardan biri "Eğitim ortamı öğrenmeyi destekleyecek bir fiziki donanıma sahipti." [K 4] şeklinde görüşünü bildirmiştir.

Eğitimciler teması altında ise yetkinlik ve kişisel nitelikler olmak üzere iki kod yer almaktadır. Katılımcılar, eğitimcilerin alanlarında yetkin olduğuna $(n=15)$ ilişkin görüşlerini şu şekilde dile getirmiştir; "Eğitimciler konusunda uzman ve uygulama deneyimi olan kişilerdi." [K 2], "Eğitimciler konuya çok iyi hazırlanmış." [K 6] ve "Ĕ̆itimcilerin alanlarında tecrübeli olmaları eğitimin kalitesini arttırdı." [K 9]. Bununla birlikte katılımcllar eğitimci kadrosunun kişisel nitelikleri $(n=6)$ ile ilgili de görüş bildirmişdir. Katılımcıların bu konuda ki görüşlerini "Ĕ̆itimcilerin iletişim becerileri oldukça iyiydi." [K 18] ve "Samimi ve iletişimi kuvvetli bir kadronun olması bizleri motive etti." [K 19] şeklinde ifade ettikleri görülmektedir.

Etkiler. Bu kategori altında katılımcılara ve öğrencilere olmak üzere iki tema yer almaktadır. Katılımcılara katkıları teması altında bilgi veren, beceri geliştiren ve farkındalık sağlayan olmak üzere üç kod bulunmaktadır. Katılımcılar eğitim programının ergen cinsel sağlığına ilişkin bilgi düzeylerini arttırdığını $(n=15)$, becerilerini geliştirdiğini $(n=9)$ ve konu ile ilgili farkındalıklarını arttırdığını $(n=6)$ belirtmiştir. Katılımcılar bilgi düzeylerinin arttığına ilişkin görüşlerini, "Çocuğun cinsel gelişimiyle ilgili yaşadı̆̆ı problemleri anlamam ve müdahalem konusunda beni güçlü kılar." [K 2], "Kendi adıma cinsel sağlıkla ilgili benim de eksik/yanlış bildiğim pek çok şeyin doğrusunu tam olarak öğrendim." [K 6] ve "Toplumsal cinsiyet eşitliği konusunda somut bilgiler edindim." [K 20] şeklinde ifade etmiştir. Katılımclar becerilerinin geliştiğine ilişkin görüşlerini "Özellikle karşılaşılan sorunlara nasıl tepki verilebileceğini ergenlik döneminde yaşanan kimlik keşfi sırasında nasıl destek olabileceğimi fark etmemi sağladı." [K 10], "Bu eğitim sayesinde öğrenciler ile cinsellik hakkında daha rahat konuşabileceğim." [K 17] ve "Bu eğitim eğitici rolümün yanında kendime çok şey kattı. Cinsellik konusunda çevremle önyargısız iletişim kurabileceğimi düşünüyorum." [K 19] şeklinde ifade ederken, farkındalık kazanmalarına ilişkin görüşlerini ise "Toplumsal cinsiyet eşitsizliği konusunda farkındalığım arttı." [K 4] ve "Günlük konuşma dilimizde yerleşmiş ayrımo ifadelerden bazılarını kullandığımın farkına varmam en büyük katkılardan biriydi." [K 11] şeklinde ifade etmiştir. Eğitici eğitiminin öğrencilere katkıları teması altında sunulan hizmetlere katkı sağlayan kodu yer almaktadır. Katılımcıların bir çoğu eğitici eğitiminin, öğrencilere yönelik sundukları hizmetlere katkı sağlayacağını $(n=$ 
12) belirtmiştir. Katılımcılar bu konudaki görüşlerini "Özellikle gelişmekte olan bireylerin kendilerindeki değişimleri tanımasına ve anlamasına yardımo olacaktır. Cinsellikle ile ilgili yaşadıkları sorunları daha kolay ifade etmelerini sağlayacak. Karşılaştıkları durumların riskli olup olmadığını ayırt edebilecektir." [K 1], "Daha çok bilgi sahibi oldum. Öğrencilerime daha yararlı olacağım." [K 6] ve "Ergenlerle çalışırken hak temelli yaklaşım, cinsiyet eşitliği flört şiddeti toplumsal cinsiyet konularında özellikle faydalı olacă̆ı kanısındayım." [K 15] şeklinde ifade etmiştir.

\section{Tartışma, Sonuç ve Öneriler}

Türkiye' deki psikolojik danışmanların önemli bir kısmı cinsellik ve cinsel gelişim konularındaki bilgi ve becerilerini yeterli görmediklerini belirtmektedir (Topkaya ve Hatipoğlu Sümer, 2010). Benzer şekilde aday psikolojik danışmanların bu alandaki yeterliliklerinin/yetkinliklerin arttırılmasında doğrudan bir role sahip olan ve seçmeli olarak sunulan cinsel sağlık eğitimi dersinin birçok lisans programında açılmadığı görülmektedir (Çuhadaroğlu, 2017). Etkili cinsel sağlık eğitimi müdahaleleri ve süreçleri irdelendiğinde eğiticilerin niteliklerinin (bilgi düzeyi, tutum, yeterlilik algısı vb.) belirleyici değişkenler arasında olduğu görülmektedir (Hedgepeth ve Helmich, 1996; Byers, Sears, Foster, 2013; Smith vd., 2011). Psikolojik danışmanların cinsel sağlık eğitimi ile ilgili kendilerinden beklenen rolü ve sorumlulukları yerine getirebilmeleri için psikolojik danışmanların daha donanımlı hale getirilmesine ihtiyaç vardır (Millner ve Upton, 2016; Sharpe, 2003). Bu çalışmayla okul psikolojik danışmanlarının cinsel sağlık eğitimi ve cinsel gelişim konularındaki yetkinliğini arttırmayı amaçlayan cinsel sağlık eğitici eğitiminin etkililiğinin incelenmesi amaçlanmıştır. Nicel ve nitel bulgular birlikte değerlendirildiğinde, cinsel sağlık eğitici eğitiminin katılımcıların ergen sağlığına ilişkin yeterlilik algılarında yükselişin yanı sıra ergen cinsel sağlığı ile ilgili bilgi ve becerilerinin artmasına katkı sağladığı belirlenmiştir. Araştırma bulgularının, psikolojik danışmanlar ve psikolojik danışman adayları ile yürütülen çalışmaların bulguları ile tutarlı olduğu görülmektedir (Ahmed vd., 2006; AlaviArjas, Farnam, Granmayeh ve Haghani, 2018; Kumcağız, Çelik, Barut ve Koçyiğit; 2013, Roche, 1998). Cinsel konularda eğitim alan psikolojik danışmanların cinsellik hakkında kendilerini daha yeterli olarak algıladıkları, güvenlerinin arttı̆̆ı ve cinsellikle ilgili müdahalelerde bulunma olasılıklarının yükseldiği bildirilmektedir (Harris ve Hays, 2008). Bogey (2008) cinsel sağlık eğitimi sunan uzmanların aldıkları ek eğitimlerin sayısının artmasına bağlı olarak cinsellikle ilgili artan bilgi düzeyinin uzmanların cinsellikle bağlantılı konuları ele alırken kendilerine daha fazla güvendiklerini rapor etmiştir.

Önleme ve krize müdahale, okul psikolojik danışmanlarının, sıklıkla sundukları ve birbirleriyle bağlantılı olan hizmetlerdir (Walsh, Barrett ve DePaul, 2007). Cinsel şiddet, psikolojik danışmanların ele almak durumunda kaldıkları krizlerden biridir (Korkut-Owen, 2015). Yapılan çalışmalarda, cinsiyetten bağımsız olarak ergenlerin önemli bir bölümünün okulda veya okul dışında fiziksel veya sözel olarak cinsel şiddete ve flört şiddetine maruz kaldıklarını bildirmişlerdir (Foshee vd., 2009; Hickman, Jaycox, Aronoff, 2004; Witkowska, 2005). Cinsel sağlık eğitimi aracılığı ile önlenmesi, sıklığı azaltılması hedeflenen olumsuz yaşantılar arasında cinsel şiddetin her türlü formu yer almaktadır (SIECUS, 2004). Bu eğitim kapsamında ele alınan "güvenli ilişkiler ve flört şiddeti", "cinsel istismara karşı koruyucu önleyici çalışmalar" temalarının psikolojik danışmanların bu konulardaki krize müdahale ve önleme hizmetlerine ilişkin yetkinliklerinin artmasına katkı sağladığı düşünülmektedir. Yarı yapılandırılmış görüşmeler sonucunda elde edilen nitel verilerde bu bulguyu desteklemektedir. Katılımcılar, eğitici eğitimininin önleyici çalışmalar yapma konusunda 
bilgilerini arttırdığını ve becerilerini geliştirdiğini, ergenlerin cinsellikle ilgili konularda yaşayabilcekleri sorunlarda müdahale etme kapasitelerine katkı sağladığını ve flört şiddeti konusunda faydalı olduğunu vurgulamışlardır. Konuya ilişkin artan bilgi düzeyi, algılanan yeterliliği de olumlu yönde etkilemektedir (Şahin, 2014, Parker, 2012).

Araştırmanın nitel bulguları göz önünde bulundurulduğunda, eğitici eğitiminin katılımcıların cinsellikle ilgili konularda hizmet sundukları bireylerle etkili iletişim kurmalarına katkı sağladığı belirlenmiştir. Bununla birlikte katılımcılar günlük yaşamlarında da cinsellikle ilgili konularda duygu ve düşüncelerini daha rahat ifade edebileceklerini belirttikleri görülmektedir. Cinsel sağlık eğitimi ile ilgili geçmişleri (cinsel sağlık eğitimi alıp almamaları, aldıkları cinsel sağlık eğitiminin niteliği vb.) psikolojik danışmanların, cinsel sağlık eğitimi sunma, cinsellikle ilgili hassas konuları ele alma ile ilgili gönüllüklerini ve rahatlık düzeylerini etkileyen önemli değişkenlerden biri olarak dikkat çekmektedir (Anderson, 2002; Cupit, 2010; Gupta, 2019; Roche, 1998, Parker, 2012). Cinsel konularda yeterli eğitim aldığını ve bilgilerinin yeterli olduğunu düşünen psikolojik danışmanlar bu hizmetleri sunmada eğitim almayan psikolojik danışmanlara göre daha rahat hissetmektedir (Roche, 1998). Bir başka ifade ile cinsel konulardaki bilgi düzeyinin artması psikolojik danışmanların cinsellikle ilgili konularda hizmet sunmadaki rahatlığını ve gönüllügüunü olumlu şekilde etkilemektedir (Gupta, 2019; Şahin, 2014; Parker, 2012). Psikolojik danışmanlar için cinsel konularda rahatlığın; cinsel duyguları ve tutumları danışanlarıyla açık şekilde tartışabilmek, danışanların cinsel davranışlarına saygı gösterebilmek ve cinsel konularda etkili iletişim kurabilmek gibi boyutları bulunmaktadır (Graham ve Smith, 1984). Cinsel sağlık eğitimi alan ergenler, eğitmenlerin cinsel konulardaki rahatlığının cinsel sağlık eğitiminin kalitesini belirleyen önemli faktörlerden biri olarak belirtmişlerdir (Byers, Sears ve Foster, 2013). Özellikle ergenlerle yürütülen müdahale çalışmalarda, "rahatlık" etkili müdahalelerin temel unsurları arasındadır (Gupta, 2019; Roche, 1998). Benzer şekilde, Cupit (2010) danışanların, psikolojik danışmanların belirli konularda rahat hissetmediğini fark ettiklerinde, o konuları tekrar gündeme getirmemeyi tercih edebildiklerini ifade etmektedir.

Cinselliğin çok boyutlu oluşu göz önünde bulundurulduğunda, doğru ve bilimsel bilginin yanı sıra bireylerin cinselliğe ilişkin tutumlarının, değerlerinin ve duygularının konuşulması cinsel sağlık eğitiminin temel odaklarından olmalıdır (Bruess ve Schroeder, 2014, SIECUS, 2004). Cinsel sağlık eğitimini etkin biçimde sunan uzmanların/eğitimcilerin niteliklerine bakıldığında, kendi cinsel değerlerine ve tutumlarına ilişkin derin bir içgörüye sahip oldukları; eğitim verdiği gruplardaki farklı değerleri ve inançları yargılamadan ele aldıkları görülmektedir (Public Health Agency of Canada [PHAC], 2008). Cinsellikle ilgili duyguların, tutumların ve değerlerin irdelenmesinde en etkili ve sıklıkla kullanılan tekniklerden birinin küçük grup tartışmaları olduğu belirtilmektedir (Cupit, 2010; Herbert ve Lohrmann, 2011). Grup tartışması, canlandırma gibi öğrenen merkezli teknikler uzmanların yeterlilik algılarının artmasında etkilidirler. Küçük grup tartı̧̧ması sırasında farklı değerlerin, tutumların ve duyguların açığa çıkması; katılımcıların kendi duygularını, tutumlarını, duygularını sorgulamasına belki de yenide düzenlemesine yol açabilmektedir (Buckelew, Adams, Irwin, Gee ve Ozer, 2008). Bu yönüyle diğerlerinin cinsellikle ilgili değerlerine ve inançlarına ilişkin farkındalıklarını arttırabilmektedir (Cupit, 2010). Bu çalışmada da küçük grup tartışması tekniğinden sıklıkla ve etkin şekilde yararlanılmasının psikolojik danışmanların farkındalıklarının artmasına katkı sağladığı düşünülmektedir. 
Bununla birlikte cinsel sağlık eğitim konusunda bir tekniğin diğer tekniklerden daha üstün ya da etkili bir öğretim yönteminden söz etmek doğru olmayacaktır (Bruess ve Schroeder, 2014; Gadd ve Hinchliffe, 2007). Farklı öğretim tekniklerinden/yöntemlerimden faydalanılan bütünleştirici bir yaklaşımın etkin bir eğitim sürecine daha fazla katkı sağlayabileceği vurgulanmaktadır (Cupit, 2010; Humphrey, 2000). Bu çalışmada canlandırmalardan, vaka tartışmalarına kadar geniş bir yelpazede katılımcıların becerilerinin de gelişmesine katkı sağlayabilecek tekniklerden yararlanılmıştır. Risk faktörlerine ve koruyucu faktörlere doğrudan odaklanan etkinliklere yer vermesi, katılımcıların eğitimin mesajlarını kişiselleştirmesine olanak sağlayacak şekilde geliştirilmiş interaktif öğretim yöntemlerin kullanılması etkili eğitimlerin özellikleri arasında kabul edilmektedir (Haberland ve Rogow, 2015; Kirby, 2007). Katılımcların süreç içinde kendilerini aktif hissetmelerini sağlayan etkinlikler de cinsel sağlık eğitimlerinin etkililiğine katkı sağlamaktadır (Herbert ve Lohrmann, 2011). Herbert ve Lohrmann (2011), etkili cinsel sağlık eğitimlerinin içeriklerini inceledikleri çalışmaları sonucunda; canlandırma, işbirlikli öğrenme ve küçük grup tartışmalarının en sık kullanılan yöntemler olduğunu bildirmişlerdir. Çalışmanın nitel bulguları incelendiğinde katılımcıların kullanılan yöntem ve tekniklerin programın etkililiğine önemli katkılar sağladığını, yanı sıra motivasyonlarını arttırdığını belirttikleri görülmektedir.

İçeriğin yanında eğitimlerin süresi de eğitsel müdahalelerin etkililiğinde rol oynayabilmektedir. Kirby (2007), katılımcıların becerilerinin ve bilgilerinin artmasında etkili olan eğitimlerin 20 saat ve üzerinde süren eğitim olduğunu bildirmiştir. Psikolojik danışmanlara sunulan cinsel sağlı eğitici eğitimi beş gün boyunca toplam 40 saat sürmüştür. Nitel bulgulara göre katılımcıların bir kısmı, eğitimin süresinin arttırılmasına yönelik öneriler getirmişlerdir. Psikolojik danışmanların mevcut bilgi düzeylerinin yetersizliğinin ve ergen cinselliğinin çok boyutluluğunun bu önerilerin gündeme gelmesinde etkili olduğu düşünülmektedir.

Psikolojik danışmanlara yönelik hazırlanan eğitici eğitiminin, Milli Eğitim Müdürlüğü ve sivil toplum kuruluşları tarafından desteklenen "Kendimi Tanıyorum" projesi kapsamında sunulması katılımcıların yönetimsel ve toplumsal engellere ilişkin kaygılarının en aza indirilmesine katkı sağladığına inanılmaktadır. Yetersiz toplumsal ve yönetimsel destek cinsel sağlık eğitiminin önündeki engellerden biri olarak değerlendirilmektedir (Cohen, Byers ve Sears, 2012). Birçok eğitimci okul yönetiminin ve velilerin desteğini alamadığ için cinsel sağlık eğitimi sunmaktan kaçındığını belirtmektedir (Smith vd., 2011). Sunulan destek aynı zamanda, psikolojik danışmanlardan riskli cinsel davranışların önlenmesinde ve sağlık cinsel gelişimin desteklenmesinde kendilerinden beklenen rolün açık bir şekilde tanımlanması, ifade edilmesi bakımından da oldukça değerlidir.

Katılımclar eğitim veren uzmanların yetkinliğinin, güçlü iletişim ve öğretme becerilerinin, alan tecrübelerinin ve yargılayıcı olmayan tutumlarının programın etkili olmasında belirleyici olduğuna dair görüşler bildirmişlerdir. Cinsel sağlık eğitimi sunan uzmanların, ihtiyaç duyulan ve uzmanlık alanlarında yer alan konulara ilişkin geniş bilgiye ve anlayışa; toplumsal cinsiyet eşitliği temelli bir cinsellik ve cinsel sağlık yaklaşımına, hassas ve tartışılması güç konularda katılımcılara destek sağlayabilecek öğretim yöntemlerini kullanma becerisine ve cinselliği ve cinsel sağlı̆̆ı özenli, yargılayıcı olmayan, olumlu ve rahat bir biçimde ele alma kapasitesine sahip olmaları beklenmektedir (PHAC, 2008). Eğitsel geçmiş ve uygulama tecrübesi uzmanlardan beklenen niteliklerin gelişmesinde önemli 
faktörler olarak karşımıza çıkmaktadır (Cohen vd., 2012). İyi yetişmiş uzmanlar etkili cinsel sağlık eğitiminin anahtarı olarak kabul edilmektedir (Barr vd., 2014). Bu çalışmada cinsel sağlık eğitimi veren uzmanların çocuklardan, yetişkinlere; velilerden öğretmenlere kadar farklı gruplara defalarca cinsel sağlık eğitimi vermiş, tecrübeli saha çalışanları olmasının sürecin verimliliğine katkı sağladığına inanılmaktadır.

Katılımcı psikolojik danışmanlar, eğitici eğitiminin toplumsal cinsiyet konusundaki bilgilerinin artmasına, toplumdaki cinsiyet temelli eşitsizlik hakkında eleştirel düşünme becerilerinin gelişmesine, toplumsal cinsiyet eşitsizliğinin kendi yaşamlarını nasıl etkilediğini sorgulamalarına destek olduğunu dile getirmişlerdir. Toplumsal cinsiyet kalıpyargılarının, olumsuz sonuçlarının görüldüğü, etkili olduğu alanlar arasında cinsellik ve cinsel sağlık da bulunmaktadır (Sen ve Östlin, 2008). Bu nedenle kapsamlı cinsel sağlık eğitimi yaklaşımları toplumsal cinsiyet eşitliği algısının güçlendirilmesine ilişkin temaları ele almaktadır (SIECUS, 2004). İlgili literatür doğrultusında (Haberland, 2015), katılımcıların, yakın ilişkilerde toplumsal cinsiyet ve gücün etkisine dikkatlerini çeken, toplumsal cinsiyet normlarının nasıl oluştuğuna ve işlediğine ilişkin eleştirel düşünmelerini kolaylaştıran, toplumsal cinsiyet rollerine ilişkin kişisel bakış açılarını ifade etmelerini sağlayan etkinliklere eğitimde yer verilmesinin bu bulguda etkili olduğu düşünülmektedir.

Çalışmanın bulguları değerlendirilirken bazı sınırlılıkların olduğu göz önünde bulundurulmak gereklidir. Bunlardan ilki Türkiye' de cinsel sağllk eğitimi veren kişilerin yeterliliklerini ölçen, geçerlik ve güvenirlik çalışması yapılmış bir ölçme aracının olmamasından dolayı psikolojik danışmanların ergen sağlığına ilişkin yeterlilik algısını ölçmek için araştırma kapsamında geliştirilen anketin kullanılmasıdır. Anketin kapsam geçerliliği uzman görüşleri ile incelenmiş ve her bir maddenin kapsam geçerlilik indeksleri hesaplanmıştır; ancak anketten toplam puan alınamadığı için kapsamlı güvenirlik analizleri yapılamamıştır. Gelecekte cinsel sağlık eğitimi veren kişilerin yeterliliklerini ölçen, bir ölçme aracının geliştirilmesi yararlı olacaktır. Çalışmanın bir diğer sınırlılığı ise psikolojik danışmanların eğitici eğitiminden elde ettikleri kazanımların kalıcılığını değerlendirmeye yönelik bir izleme ölçümünün yapılmamış olmasıdır. Gelecekteki çalışmalarda izleme ölçümlerinin de yer alması, eğitici eğitiminin uzun süreli etkileri konusunda bir anlayış kazanılmasını sağlayacaktır. Çalışmanın son sınırlılığı ise araştımanın nicel boyutunda kullanılan yöntemin gönüllü katılımcı sayısının yeterli olmamasından dolayı kontrol grupsuz bir deneysel desen olarak gerçekleştirilmesidir. Gelecekte kontrol grubunun da yer aldığı çalışmalar yapılması ile daha güvenilir sonuçlar elde edilebilir.

Araştırmanın bulguları ve ilgili literatür birlikte değerlendirildiğinde; psikolojik danışmanların, cinsel sağlık eğitimi sunma ile ilgili donanımlarını ve rahatlıklarını arttırmaya yönelik derslerin lisans programlarındaki sayısının arttırılması ve zorunlu hale getirilmesinin ergenlerin sağlıklı gelişimlerine katkı sağlayacağı düşünülmektedir (Hatipoğlu Sümer, 2007; Sharpe, 2003). Cinsel gelişim ile bağlantılı konuların uygun teorik derslerin içeriğinde tartışılmasına, dahil edilmesine olanak sağlanması psikolojik danışmanların daha geniş bir anlayış geliştirmelerine katkı sağlayabilecektir. Bununla birlikte cinsel sağlık eğitim almamış, farklı okullarda halen çalışan psikolojik danışmanların sayısının azımsanmayacak kadar çok olduğu düşünüldüğünde hizmet içi eğitimlere olan ihtiyaç açıktır. Psikolojik danışma ve rehberlik hizmetleri yönetmeliğinde, psikolojik danışmanların cinsel sağlık eğitimi sunmasına ilişkin rolünün ve cinsel sağlık eğitimi kavramının daha açık şekilde tanımlanması bu hizmetin yaygınlaşmasını hızlandıracaktır. 


\section{Kaynakça}

Ahmed, N., Flisher, A. J., Mathews, C., Jansen, S., Mukoma, W., \& Schaalma, H. (2006). Process evaluation of the teacher training for an AIDS prevention programme. Health Education Research, 21(5), 621-632.

Alavi-Arjas, F., Farnam, F., Granmayeh, M., \& Haghani, H. (2018). The effect of sexual and reproductive health education on knowledge and self-efficacy of school counselors. Journal of Adolescent Health, 63(5), 615-620. DOI: 10.1016/j.jadohealth.2018.05.031

Anderson, M. J. (2002). Counselor comfort with sexual issues. (Doctoral dissertation, University of New Orleans). Available from ProQuest Dissertations and Theses database (UMI No. 3061355).

Bandura, A. (1982). Self-efficacy mechanism in human agency. American Psychologist, 37(2), 122-147.

Barr, E. M., Moore, M. J., Johnson, T., Forrest, J., \& Jordan, M. (2014). New evidence: Data documenting parental support for earlier sexuality education. Journal of School Health, 84(1), 10-17. DOI: 10.1111/josh.12112

Bogey, L. A. (2008). Addressing sexuality with clients: A manual for therapists in training (Doctoral dissertation). Available from ProQuest Dissertations and Theses database. (UMI No. 3308670)

Bruess, C. E., \& Schroeder, E. (2014). Sexuality education: Theory and practice (6th ed.). Burlington, MA: Jones \& Bartlett.

Buckelew, S. M., Adams, S. H., Irwin Jr, C. E., Gee, S., \& Ozer, E. M. (2008). Increasing clinician self-efficacy for screening and counseling adolescents for risky health behaviors: results of an intervention. Journal of Adolescent Health, 43(2), 198-200.

Bulut, F., \& Gölbaşı, Z. (2009). Adolesan kızların cinsellikle ilgili konularda anneleri ile olan iletişimlerinin değerlendirilmesi. TAF Preventive Medicine Bulletin, 8(1), 27-36.

Byers, E. S., Hamilton, L. D., \& Fisher, B. (2017). Emerging adults' experiences of middle and high school sexual health education in New Brunswick, Nova Scotia, and Ontario. The Canadian Journal of Human Sexuality, 26(3), 186-195. DOI: 10.3138/cjhs.2017-0006

Byers, E. S., Sears, H. A., \& Foster, L. R. (2013). Factors associated with middle school students' perceptions of the quality of school-based sexual health education. Sex Education, 13(2), 214-227. DOI: 10.1080/14681811.2012.727083

Byers, E. S., Sears, H. A., Voyer, S. D., Thurlow, J. L., Cohen, J. N., \& Weaver, A. D. (2003). An adolescent perspective on sexual health education at school and at home: I. High school students. Canadian Journal of Human Sexuality, 12(1),1-17.

Byers, E. S., Sears, H. A., \& Weaver, A. D. (2008). Parents' reports of sexual communication with children in kindergarten to grade 8. Journal of Marriage and Family, 70(1), 86-96.

Colbert, R. D., \& Magouirk Colbert, M. (2003). School counselor involvement in culture centered education reform. In P. B. Pederson \& J. C. Carey (Eds.), Multicultural counseling in schools: A practical handbook (pp. 3-26). Boston, MA: Allyn \& Bacon. 
Cohen, J. (1988). Statistical power analysis for the behavioral sciences (2nd ed.). Hillsdale, NJ: Erlbaum.

Cohen, J. N., Byers, E. S., \& Sears, H. A. (2012). Factors affecting Canadian teachers' willingness to teach sexual health education. Sex Education, 12(3), 299-316. DOI: 10.1080/14681811.2011.615606

Corey, M. S., Corey, G., \& Corey, C. (2014). Groups: Process and practice (8th ed.). Belmont: Brooks/Cole.

Council for Accreditation of Counseling and Related Educational Programs (CACREP). (2016). CACREP accreditation manual. Retrieved from: http://www.cacrep.org/wpcontent/uploads/2017/08/2016-Standards-with-citations.pdf

Creswell, J. W. (2012). Research design (4th ed.). London: SAGE.

Creswell, J. W., \& Plano Clark, V. L. (2017). Designing and conducting mixed methods research (3th ed.). Los Angeles: SAGE.

Cupit, R. W. (2010). Counselors' comfort levels and willingness to discuss sexual issues with couples they counsel (Doctoral dissertation, University of New Orleans). Retrieved from: https://scholarworks.uno.edu/td/1150

Çuhadaroğlu, A. (2017). The effects of sex education on psychological counselling students in Turkey. Sex Education, 17(2), 209-219. DOI: 10.1080/14681811.2016.1164132

DeLucia-Waack, J. L. (2006). Leading psychoeducational groups for children and adolescents. Thousand Oaks, CA: Sage.

Erbil, N., Orak, E., \& Bektaş, A. E. (2010). Anneler cinsel eğitim konusunda ne biliyor, kızlarına ne kadar cinsel eğitim veriyor. Uluslararası İnsan Bilimleri Dergisi, 7(1), 366-383.

Eroğlu, K. ve Gölbaşı, Z. (2005), Cinsel eğitimde ebeveynlerin yeri: ne yapıyorlar, Ne yaşıyorlar? Atatürk Üniversitesi HYO Dergisi, 8(2), 12-21.

Fisher, J.D., Fisher, W.A., Miscovich, S.J., Kimble, D.L. ve Malloy, T. (1996). Changing AIDS risk behavior: Effects of an intervention emphasizing AIDS risk reduction information, motivation, and behavioral skills in a university student population. Health Psychology, 15, 114-123.

Fisher, J.D. \& Fisher, W.A. (1992). Changing AIDS risk behavior. Psychological Bulletin, 111: 455-474.

Finer, L. B. \& Philbin, J. M. (2013). Sexual initiation, contraceptive use, and pregnancy among young adolescents. Pediatrics, 131(5), 886-891. DOI: 10.1542/peds.2012-3495

Forhan, S. E., Gottlieb, S. L., Sternberg, M. R., Xu, F., Datta, S. D., McQuillan, G. M., ... \& Markowitz, L. E. (2009). Prevalence of sexually transmitted infections among female adolescents aged 14 to 19 in the United States. Pediatrics, 124(6), 1505-1512. DOI: 10.1542/peds.2009-0674

Foshee, V. A., Benefield, T., Suchindran, C., Ennett, S. T., Bauman, K. E., Karriker-Jaffe, K. J., ... \& Mathias, J. (2009). The development of four types of adolescent dating abuse and selected demographic correlates. Journal of Research on Adolescence, 19(3), 380-400. 
Gadd M. \& Hinchliffe J. (2007). Jiwsi: A pick ' $n$ ' mix of sex and relationships education activities. London: FPA.

Garcia, C. K. (2015). Sexual health education in Quebec schools: A critique and call for change. The Canadian Journal of Human Sexuality, 24(3), 197-204. DOI: 10.3138/cjhs.243-C01

Goldman, J. D. (2008). Responding to parental objections to school sexuality education: A selection of 12 objections. Sex Education, 8(4), 415-438.

Goldman, J. D. (2011). An exploration in health education of an integrated theoretical basis for sexuality education pedagogies for young people. Health Education Research, 26(3), 526541. DOI: $10.1093 /$ her/cyq084

Graham, C. A., \& Smith, M. M. (1984). Operationalizing the concept of sexuality comfort: Applications for sexuality educators. Journal of School Health, 54(11), 439-442.

Gupta, S. (2019). Indian counselors' comfort and interventions with sexuality-related concerns. SAGE Open, 9(1), 1-13. DOI: 10.1177/2158244018821760

Gürsoy, E. ve Gençalp, N. S. (2010). Cinsel sağlık eğitiminin önemi. Sosyal Politika Çalışmaları Dergisi, 23(23), 29-36.

Haberland, N. A. (2015). The case for addressing gender and power in sexuality and HIV education: a comprehensive review of evaluation studies. International Perspectives on Sexual and Reproductive Health, 41(1), 31-42. DOI: 10.1363/4103115

Haberland, N., \& Rogow, D. (2015). Sexuality education: emerging trends in evidence and practice. Journal of Adolescent Health, 56(1), S15-S21. DOI: 10.1016/j.jadohealth.2014.08.013

Harris, S. M., \& Hays, K. W. (2008). Family therapist comfort with and willingness to discuss client sexuality. Journal of Marital and Family Therapy, 34, 239-250.

Hatipoğlu Sümer, Z. (2007). Neglected component of counselor education: Sexuality education. In R. Özyürek, F., Korkut-Owen, D. W. Owen (Eds.), Gelişen Psikolojik Danışma ve Rehberlik. (pp. 183-200). Ankara: Nobel Yayın Dağıtım

Hedgepeth, E. ve Helmich, J. (1996). Teaching about Sexuality and HIV. New York: NY University Press.

Herbenick, D., Reece, M., Schick, V., Sanders, S. A., Dodge, B., \& Fortenberry, J. D. (2010). Sexual behavior in the United States: Results from a national probability sample of men and women ages 14-94. The Journal of Sexual Medicine, 7, 255-265.

Herbert, P. C., \& Lohrmann, D. K. (2011). It's all in the delivery! An analysis of instructional strategies from effective health education curricula. Journal of School Health, 81(5), 258-264. DOI: 10.1111/j.1746-1561.2011.00586.x

Hickman, L. J., Jaycox, L. H., \& Aronoff, J. (2004). Dating violence among adolescents: Prevalence, gender distribution, and prevention program effectiveness. Trauma, Violence, $\mathcal{E}$ Abuse, 5(2), 123-142.

Humphrey, K. M. (2000). Sexuality counseling in counselor preparation programs. The Family Journal: Counseling and Therapy for Couples and Families, 8, 305-308.

James, S. H. (1999). School counselors' roles in cases of child sexual behavior. Professional School Counseling, 2(3), 211-217. 
Johanson, G. A., \& Brooks, G. P. (2010). Initial scale development: sample size for pilot studies. Educational and Psychological Measurement,70(3), 394-400. DOI: $10.1177 / 0013164409355692$

Kirby, D. (2007). Emerging answers 2007: Research findings on programs to reduce teen pregnancy and sexually transmitted diseases. Washington, DC: National Campaign to Prevent Teen and Unwanted Pregnancy.

Korkmaz Çetin. S., Bildik, T., Erermiş, S., Demiral, N., Özbaşaran, B., Tamar, M. ve Aydın, C. (2008). Erkek ergenlerde cinsel davranış ve cinsel bilgi kaynakları: Sekiz yıl arayla değerlendirme. Türk Psikiyatri Dergisi, 19(4), 390-397.

Korkut-Owen, F. (2015). Okul temelli önleyici rehberlik ve psikolojik danışma. Ankara: Anı Yayıncilik.

Kumcağız, H., Çelik, S. B., Barut, Y., \& Koçyiğit, M. (2013). Psikolojik danışman adaylarının cinsel sağlık eğitimi dersine ilişkin görüşleri. Kırşehir Eğitim Fakültesi Dergisi, 14(3), 227242.

Lloyd, C. B. (2010). The role of schools in promoting sexual and reproductive health among adolescents in developing countries. In Malarcher S. (Eds.) Social determinants of sexual and reproductive health Informing future research and programme implementation. Geneva: World Health Organization.

Mann, B. L. (2006) Case study research and online learning. In B. L. Mann (Eds.), Case study research on web-based learning (pp. 70-79). London: Information Science Publishing.

Meyers, A. and Swerdlik, M. (2003). School-based health centers: Opportunities and challenges for school psychologists. Psychology in the Schools, 40, 253-264. DOI: 10.1002/pits.10085

Millner, V., \& Upton, A. W. (2016). Sexually active and sexually questioning students: The role of school counselors. Ideas and research you can use: VISTAS 2016. Retrieved from: http://www.counseling.org/knowledge-center/vistas

Miles, M. B. \& Huberman, A. M. (1994). Qualitative data analysis (2nd ed.). Thousand Oaks, CA: SAGE.

Parker, L. P. (2012). High school counselors' attitudes toward the sexuality of students with intellectual disabilities. (Doctoral dissertation, University of Alabama, Tuscaloosa). Retrieved from: http://acumen.lib.ua.edu/content/u0015/0000001/000 1076/u0015 0000001 0001076.pdf

Parker, T. (2015). Durum çalışması. F.N. Seggie ve Y. Bayyurt (Ed.), Nitel Araştırma:Yöntem, Teknik, analiz ve yaklaşımları (s. 119-133) içinde. Ankara: Anı Yayıncılık.

Public Health Agency of Canada (PHAC). (2008). Canadian guidelines for sexual health education. Ottawa : Public Health Agency of Canada.

Roche, B. F. (1998). A study of the relationships among human sexuality education, sexual comfort, HIV knowledge, and willingness of high school counselors to respond to adolescents about sexual issues. (Doctoral dissertation, New York University). Available from ProQuest Dissertations and Theses database (UMI No. 9819879). 
Sağlık Bakanlığ1 (2010). Cinsel sağllk ve üreme sağlığı ulusal stratejik eylem planı. Ankara: Ana Çocuk Sağlı̆̆ı ve Aile Planlaması Genel Müdürlüğü.

Sedgh, G., Finer, L. B., Bankole, A., Eilers, M. A., \& Singh, S. (2015). Adolescent pregnancy, birth, and abortion rates across countries: levels and recent trends. Journal of Adolescent Health, 56(2), 223-230. DOI: 10.1016/j.jadohealth.2014.09.007

Sen, G. \& Östlin, P. (2008) Gender inequity in health: Why it exists and how we can change it? Global Public Health, 3:sup1, 1-12. DOI: 10.1080/17441690801900795

Sexuality Information and Education Council of the United States (SIECUS) (2004). Guidelines for comprehensive sexuality education (3th Ed.). New York: SIECUS.

Sharpe, T. H. (2003). Adolescent sexuality. Family Journal: Counseling and Therapy for Couples and Families, 11(2), 210-215.

Siyez, D.M. ve Siyez E. (2007). Ergenlerin cinsel yaşam deneyimlerinin bazı psiko-sosyal değişkenler açısından değerlendirilmesi. Türk Üroloji Dergisi, 33(1), 56-63.

Simons, J. D., Brian, H., \& Bahr, M. W. (2017). School counselor advocacy for lesbian, gay, and bisexual students: Intentions and practice. Professional School Counseling, 20(1a), 10962409. DOI: 10.5330/1096-2409-20.1a.29

Smith, A., Schlichthorst, M., Mitchell, A., Walsh, J., Lyons, A., Blackman, P., \& Pitts, M. (2011). Sexuality education in Australian secondary schools: Results of the 1st national survey of Australian secondary teachers of sexuality education 2010. Melbourne: Australian Research Centre in Sex, Health and Society.

Sousa, R. (2018). Counseling supervisor self-efficacy and theoretical orientation as predictors of comfort with sexuality (Doctoral dissertation, Capella University). Available from ProQuest Dissertations and Theses database (UMI No. 10745405).

St Leger, L. H. (1999). The opportunities and effectiveness of the health promoting primary school in improving child health - a review of the claims and evidence. Health Education Research, 14(1), 51-69.

Şahin, G. N. (2014). Developing and testing the effectiveness of the teacher training program on child sexual development (Master's thesis, Middle East Technical University). Retrieved from: http://tez2.yok.gov.tr/

Topkaya, N., \& Hatipoğlu Sümer, Z. (2010). Rehberlik ve psikolojik danışmanlık öğrencilerinin cinsel bilgi kaynakları, yeterlilik algıları ve bilgi ihtiyaçları. Türk Psikolojik Danışma ve Rehberlik Dergisi, 4(34), 139-148.

United Nations Population Fund (UNFPA). (2014). Operational guidance for comprehensive sexuality education. A focus on human rights and gender. New York: UNFPA

Veneziano, L., \& Hooper, J. (1997). A method for quantifying content validity of health related questionnaires. American Journal of Health Behavior, 21,67-70.

Walsh, M. E., Barrett, J. G., \& DePaul, J. (2007). Day-to-day activities of school counselors: Alignment with new directions in the field and the ASCA National Model@. Professional School Counseling, 10(4), 2156759X0701000410. 
Walsh, J. L., Senn, T. E., Scott-Sheldon, L. A., Vanable, P. A., \& Carey, M. P. (2011). Predicting condom use using the Information-Motivation-Behavioral Skills (IMB) model: a multivariate latent growth curve analysis. Annals of Behavioral Medicine, 42(2), 235-244. DOI: 10.1007/s12160-011-9284-y

Witkowska, E. (2005). Sexual harassment in schools-prevalence, structure and perceptions. Stockholm: Arbete och Hälsavetenskaplig Skriftserie.

World Economic Forum [WEF]. (2018). The Global gender gap report 2018. Retrieved from: http://www3.weforum.org/docs/WEF GGGR 2018.pdf

Yıldırım, A. ve Şimşek, H. (2006). Sosyal bilimlerde nitel araştırma yöntemleri (5. baskı). Ankara: Seçkin Yayıncılık.

Zeren, F. ve Gürsoy, E. (2018). Neden cinsel sağl1k eğitimi? Düzce Üniversitesi Sağllk Bilimleri Enstitüsü Dergisi, 8(1), 29-33. 